\title{
The choice for multilateralism: Foreign aid and American foreign policy
}

\author{
Helen V. Milner • Dustin Tingley
}

Published online: 15 September 2012

(C) Springer Science+Business Media New York 2012

\begin{abstract}
Why do governments choose multilateralism? We examine a principalagent model in which states trade some control over the policy for greater burden sharing. The theory generates observable hypotheses regarding the reasons for and the patterns of support and opposition to multilateralism. To focus our study, we analyze support for bilateral and multilateral foreign aid giving in the US. Using new survey data, we provide evidence about the correlates of public and elite support for multilateral engagement. We find weak support for multilateralism and deep partisan divisions. Reflecting elite discourse, public opinion divides over two competing rationales - burden sharing and control-when faced with the choice between multilateral and bilateral aid channels. As domestic groups' preferences over aid policy diverge from those of the multilateral institution, maintaining control over aid policy becomes more salient and support for multilateralism falls.
\end{abstract}

Keywords International institutions $\cdot$ Multilateralism $\cdot$ Domestic politics $\cdot$ Public opinion · Foreign aid

JEL F35 · F55 · F59

\section{Introduction}

In pursuing their foreign policies, governments may choose to engage bilaterally or multilaterally. Bilateralism refers to a set of policies that are not coordinated with

Electronic supplementary material The online version of this article (doi:10.1007/s11558-012-9153-x) contains supplementary material, which is available to authorized users.

We would like to thank Torben Behmer for research assistance, the TRIPS team for access to their survey, seminar audiences at APSA, IPES, Washington University at St. Louis, reviewers, the editor, and Leo Baccini, Ahmed Faisal, Erin Graham, Robert Keohane, Randy Stone, Sarah Bermeo, Tana Johnson, Shana Marshall, Ken Schultz, David Lake, Stephen Kaplan, and Kevin Young for excellent feedback.

H. V. Milner $(\bowtie)$

Princeton University, Princeton, USA

e-mail: hmilner@princeton.edu

D. Tingley

Harvard University, Cambridge, USA

e-mail: dtingley@gov.harvard.edu 
other countries and/or that engage with one other country alone. ${ }^{1}$ Multilateralism implies adopting a coordinated approach among three or more states. In much of the post-World War II period, the US has pursued a policy of international engagement through multilateralism (Kupchan and Trubowitz 2007, pg. 158). Its multilateral engagements have been notable in many areas of foreign policy, from NATO in military security to the WTO in trade policy (Holsti 2004, pg. 287). Theories and evidence about why governments choose multilateralism are few (e.g., Hawkins et al. 2006; Ikenberry 2001; Ruggie 1993).

We focus on the choice between bilateral foreign aid, which a donor country gives directly to a recipient, and multilateral foreign aid, which a donor country gives to a multilateral institution, such as the World Bank, which pools funds from many countries and allocates aid to recipients. Aid is an interesting case for exploring the broader question. First, aid is an important instrument of influence because it can affect recipient country policies (Baldwin 1986; Bueno de Mesquita and Smith 2007; Kuziemko and Werker 2006). Aid is important for both security and economic policy, and hence involves significant political stakes. Second, there is a fairly clear distinction between a policy of bilateral aid and one of multilateral giving. Bilateral aid is given directly to a foreign country or to groups within it. In a multilateral policy, the US and other countries either coordinate their aid giving or they give aid to an international institution, like the World Bank or a regional development bank, which then distributes that aid according to the institution's own decision process. For close to 60 years, the US has chosen to give some of its aid through multilateral channels; this amount has tended to be small, usually between 10 and $30 \%$ of its total aid. The World Bank has often been the largest recipient of this multilateral aid. The choice of how to send aid is especially interesting in light of evidence that multilateral aid is often more efficient than bilateral aid (Balogh 1967; Easterly and Pfutze 2008; Lumsdaine 1993; Maizels and Nissanke 1984; Martens et al. 2002). It is more likely to follow OECD rules for best practices in aid and thus is less likely to serve donor's priorities than recipient needs (Easterly and Pfutze 2008; Martens et al. 2002). ${ }^{2}$

Recent work suggests multilateralism involves delegation in a principal-agent setting, and we seek to develop this argument (Hawkins et al. 2006; Nielson and Tierney 2003; Tierney 2006). States may want to delegate to a common agent under an arrangement where others also agree to commit resources but cede direct control to the agent. The cost is some loss of control over aid policy; the gain is a coordinated policy that pools resources. Others have claimed that multilateralism arises for different reasons. For instance, Rodrik (1996) claims it is due to the better ability of multilateral organizations to enforce conditions on recipients. McKeown (2009) suggests that the US uses multilateral organizations as a means of getting its way through informal influence (see also Stone 2011). Others have argued that multilateralism is a way for powerful states to bind themselves and convince others to cooperate with them (Lake 2009) or that normative pressure induce states to cooperate multilaterally (Ruggie 1993).

\footnotetext{
${ }^{1}$ The distinction between bilateral and unilateral relations in foreign policy terms is hard to maintain. Most policies are directed at particular countries, and hence even if chosen by the US alone they are part of a bilateral relationship.

${ }^{2}$ Note that some find no difference between multilateral and bilateral aid in their effects (e.g., Rajan and Subramanian (2008)).
} 
To our knowledge, few, if any, studies have presented evidence bearing directly on theories about multilateralism. We present one type of evidence by analyzing public opinion on multilateralism. We do not expect the public to understand principal-agent theory, but we seek to examine whether their beliefs are consistent with hypotheses derived from this theory. Public beliefs about foreign policy can be informative about government behavior for two critical reasons. First, public opinion is generally thought to act as a broad constraint on democratic governments; governments do not want to be seen as "out of step" with their publics (Canes-Wrone 2006; Erikson et al. 2002; Page and Shapiro 1992). As one recent study of US foreign policy noted, "Both Congress and the President have become reluctant to actively pursue foreign policy agendas that are at odds with public opinion" (Campbell et al. 2003, pg. 144). Public views on foreign policy can reach the ears of political leaders and can affect their thinking (PIPA 2001). ${ }^{3}$ A recent OECD report on US aid policy (OECD/DAC 2006, pg. 11), for instance, noted the importance of public attitudes: "Given the influence of public opinion in matters of development assistance and the public misunderstanding of the size and role of American aid, public awareness should be a priority task for the government and its development partners." Hence many expect that policy will be broadly consistent with majority public opinion (Aldrich et al. 1989).

Second, public opinion is likely to reflect elite attitudes. Scholars have shown that even though the public does not know a lot about foreign policy, individuals are able to develop beliefs based on the cues sent by elites that they listen to (Lupia 1994; Sniderman et al. 1991). Zaller (1992) has argued that publics gain political knowledge and develop their preferences from listening to the tenor of elite discourse. And Berinsky (2007) has further claimed that elite discourse will shape public opinion: "We would therefore expect that citizens could use the position of a prominent elite as a reference point and decide whether to support or oppose a policy based on that position, even in the absence of explicitly contradictory messages. In effect, citizens delegate the difficult process of arriving at an opinion on a complicated policy matter to trusted political experts" (pg. 978). Individuals will use the cues sent by leading political actors to develop their opinions on policy, and hence elite discourse will shape public support for foreign policies. We do not try to disentangle elite and public opinion in this paper; instead we present evidence on both to examine our argument about multilateralism. Our point is simply that exploring public opinion is informative because it can tell us much about the nature of elite discourse over foreign policy.

Interestingly, the American public and elites both exhibit caution toward the use of multilateral aid but also recognize its benefits. Like other foreign policy scholars, we find coherent sets of preferences among the public in a number of surveys (Aldrich et al. 1989, 2006). Having multiple surveys conducted at different points in time gives us greater confidence in our results and suggests that the attitudes expressed may be fairly representative. Our surveys, however, cover only a small slice of time, roughly 3 to 4 years, and hence cannot provide us with much temporal variation. Our evidence shows that attitudes about different means of engagement divide along partisan lines and hinge on individuals' beliefs about the importance of American control of foreign policy

\footnotetext{
${ }^{3}$ A 2004 sample of House and Senate members asked how important public opinion was for the formation of foreign policy. On a $0-10$ scale, with 0 not at all influential and 10 extremely influential, average responses were 7 and 7.5 for the House and Senate, respectively (Chicago Council 2005).
} 
versus the need for burden sharing. Individuals are more likely to prefer multilateralism when their preferences for aid policy differ less from those of the international institution. An original survey experiment provides some further evidence that the degree of divergence in preferences over aid policy between the international institution and the various domestic principals shapes attitudes toward multilateralism.

This paper continues in four sections. First, we discuss how the principal-agent (PA) model sheds light on the choice between multilateral and bilateral aid giving. The theory is associated with several testable hypotheses about preferences for multilateralism. Second, we introduce a new set of surveys that provide evidence about these theoretical arguments. Our analysis includes an elite subsample of our national survey to see if their attitudes are consistent with those of the general public, as well as a sample of International Relations scholars. Third, we provide evidence from a survey experiment showing how the structure of preferences among principals and the agent affects support for multilateralism. We conclude with thoughts about multilateralism and international institutions.

\section{Principal-Agent Models and the Politics of Multilateralism}

Why do countries choose multilateralism over bilateralism? Bilateralism refers to policies that are not coordinated with other countries and/or that engage with another country singly. Multilateralism, by contrast, involves both the coordination of policy among three or more states, and coordination around a series of generalized principles of conduct. Multilateralism involves "principles which specify appropriate conduct for a class of actions without regard to the particularistic interests of the parties or the strategic exigencies that may exist in any specific occurrence" (Ruggie 1993, pg. 11). Ruggie notes that multilateralism may not involve a formal international institution. While we agree conceptually, in foreign aid multilateralism has involved coordination through international or regional institutions like the World Bank, regional development banks, the UN, and the EU. Not all forms of multilateralism involve delegation to international institutions, but all coordination of policy among countries that involves delegation to an international institution is a form of multilateralism. We focus on these multilateral institutions, but future work could examine less institutionalized forms of multilateralism.

\subsection{Principal-Agent Theory}

In PA models in international relations, governments are principals who have a choice of whether to delegate policy-making to agents, namely international institutions (Hawkins et al. 2006; Nielson and Tierney 2003; Tierney 2006). This delegation involves policy coordination among states and hence it implies multilateralism by the standard definition. Here we relax the unitary state assumption and focus on different groups within the country as important principals, in addition to foreign governments. ${ }^{4}$ In modern democratic societies, long chains of delegation affect all

\footnotetext{
${ }^{4}$ Recent economic models also use a principal-agent framework to model the choice for multilateralism, but they assume a unitary donor government (Hagen 2006; Svensson 2000). This assumption clearly differentiates their work from ours.
} 
types of policies. Publics elect leaders, who in turn appoint agency directors who in turn rely on staffs and subnational actors for implementation. Foreign aid, whether bilateral or multilateral, features long chains of delegation that cross national boundaries (Martens et al. 2002). Our question centers around adding one more link to this long chain: the decision to coordinate and implement policies through an international institution, rather than directly with the foreign country. ${ }^{5}$

In this section we lay out the three key steps in our PA argument about multilateralism. First, we discuss the benefits of multilateralism from a PA perspective, that is, the importance of burden sharing. Second, we delineate the major costs of multilateralism, which involves some loss of control over policy. Finally, we point out how the structure of preferences domestically can affect the choice of multilateralism through its different costs for different groups. We also present evidence from the views of US foreign policy elites on burden sharing and control to show that they are important in the minds of American policy makers.

Multilateralism is associated with the choice to delegate to an international institution, and hence PA models seem well suited to explain the choice for multilateralism. Principals have an incentive to delegate because they do not have the knowledge or ability to make decisions as well as the agent. For delegation to occur, the principals must benefit from reducing transaction costs and/or resolving collective action problems. Delegation raises the issue of control since the principals cannot observe or direct all actions the agent takes, and hence the agent may make decisions that the principals might not desire. If there is divergence in preferences between the principals and the agent, then this imperfect observation creates the possibility that the agent does not promote the preferences of the principals, i.e., agency slack. The principals try to minimize their loss of control, while maximizing the contributions of the agent. This dilemma animates the dynamics of support for multilateralism. If PA models have empirical support, we hypothesize that political elites and the public should think about and debate multilateralism in PA terms, even if they do not understand the PA models themselves.

The first step in our argument focuses on the gains from multilateralism, which should animate the reasons that people support it. A crucial gain from delegation is burden sharing, which involves how the costs of the provision of collective public goods should be shared among countries. We hypothesize that support for multilateralism should reflect this. If states are making decisions about the provision of global public goods, there is a likelihood of under-provision as each one tries to free ride on the efforts of others. Multilateral security organizations, like NATO, and economic aid organizations, like the EU and World Bank, help countries to overcome such collective action problems and provide greater amounts of public goods (such as poverty or disease reduction) for more countries. ${ }^{6}$

Foreign aid manifests collective action dilemmas: "From the perspective of a recipient country's welfare, incentives for any one donor to shirk on activities that

\footnotetext{
${ }_{5}^{5}$ Aid giving is complex. Some bilateral aid is allocated to a country but given to an NGO for delivery; and some multilateral aid, like debt relief, is not really channeled to the foreign recipient. On average, however, multilateral aid involves at least one extra link in the PA chain of delegation.

${ }^{6}$ Burden sharing within international institutions is a topic of significant interest. Early research pointed out that countries will share burdens differently depending on their size, with the largest countries providing the most (Olson and Zeckhauser 1966).
} 
maximize overall development in favor of activities that contribute to donor-specific goals strengthen as the number of donors increase" (Knack and Rahman 2008, pg. 334). In aid, the World Bank can help solve this free riding problem and facilitate burden sharing. For example, in the World Bank regular replenishments of donor commitments to the IDA have required that a certain number of donors agree to commit to a substantial level of aid giving in order to move forward. This procedure forces some sizable number of countries to make their commitments public and to avoid free riding. The IDA replenishment procedures have fostered greater burden sharing in a number of cases where countries seemed to want to refuse to commit aid dollars (Mason and Asher 1973, pg. 410-415). It is not necessarily the case that burden sharing increases the overall aid budget in a country; it may simply shift the allocation more toward multilateral aid. But burden sharing does imply that more multilateral aid from one donor induces more from other donors.

In the US, the importance of burden sharing in aid through multilateral organizations has been noted by policy makers. In testimony to the US Congress, for example, Treasury Secretary Robert Rubin noted that the World Bank's International Development Association (IDA) "is the world's largest lender of concessional resources for projects in [public goods provision like] health, primary education, nutrition, safe drinking water, proper sanitation; and in IDA for every dollar that we [the US] put up, roughly speaking $\$ 8.5$ is lent [by others]" (Rubin 1999, pg. 6). Members of Congress and Treasury Secretaries often point out that reducing support for multilateral organizations would lead to reductions in aid from other countries. For example, Representative Long noted this with respect to the World Bank's International Development Association (IDA): "Is it not true if we cut this...that this will have a multiplier effect in causing every other contributing nation to make a significant reduction?" (Congressional Record 1993, pg. 13159-13160). ${ }^{7}$ The burden sharing nature of multilateral organizations means that one country's reductions in multilateral funding are likely to lead to substantially larger cuts overall as other countries also contribute less. While this may not reduce overall aid budgets from all donors, it is very likely to change the mix of countries and types of projects that get funded. Multilateral and bilateral aid for a country are sometimes complements and sometimes substitutes (Fleck and Kilby 2006a, pg. 232). Burden sharing implies crosscountry complements: more multilateral aid from one country leads to more from other donor countries.

The second step in our argument is to delineate the costs of multilateralism. PA theory makes clear the connection between the benefits from burden sharing and the costs of such delegation, which involves some loss of control. In aid policy, once the US delegates aid to the World Bank, it loses some (of course, not all) amount of control over who gets the aid, what projects are funded, and what conditions are imposed on recipients. Some scholars have argued that multilateral institutions like the World Bank and IMF are significantly controlled by "powerful" states (Dreher and Jensen 2007; McKeown 2009; Stone 2002, 2011; Voeten 2001). This position

\footnotetext{
${ }^{7}$ Nearly 20 years later this theme continued. "The Kasich amendment would cut $\$ 56$ million, but, in fact, it has the impact, because it is leveraged 118 times, which makes it undoubtedly the most single cost-effective element in our entire foreign aid budget... The capital contribution to the World Bank eliminated by this amendment leverages burden-sharing by other countries at a ratio greater than $\$ 4$ for every $\$ 1$ of US contribution" (Congressional Record 1977, pg. 13159-60).
} 
does not completely vitiate our argument because a number of scholars, including many of those cited above, agree that these institutions still have some leeway. As one recent study of aid policy notes, "results [are] largely consistent with significant US influence over World Bank lending, but through evolving rather than stable relationships...US interests in and policy toward the World Bank change frequently with presidential administrations and with economic and political circumstances" (Fleck and Kilby 2006a, pg. 237). Many analysts, such as Hawkins et al. (2006), Gutner (2005), Gutner and Thompson (2010), and Boas and McNeil (2003, pg. 23), claim that international institutions have significant autonomy. Some point out that having multiple principals, in the sense of countries with divergent interests, can lead to greater slack for the institution, thus noting another way in which control may be an issue (Martin 2006; Nielson and Tierney 2003). Moreover, many political actors in the US, as noted below, believe that such multilateral institutions take control of policy away from national actors. Whether true or not, some elites, especially conservatives, believe that the World Bank usurps American control over aid policy, and this belief drives domestic politics.

Foreign policy elites voice concerns about loss of control frequently, and this has been especially true for Republicans. In 1972, a subcommittee of the House Appropriations committee issued this missive to President Nixon: "The committee is deeply concerned over the trend to direct an increasing amount of US foreign assistance through the multilateral institutions while at the same time decreasing the bilateral aid program...The same degree of detailed examination which is possible in the bilateral foreign assistance programs is impossible in the multilateral assistance programs. The Congress does not know when, where, or how the budget requests will be disbursed by these multilateral organizations because they do not justify their requests by specific project" (House 1972, pg. 33). A House minority report several years later echoed similar concerns (Gwin 1994; House 1977, pg. 72-73). In the 1980s, some members of Congress were infuriated that loans from the World Bank were flowing to China, and in the early 1990s they objected to funds flowing to Iran. Between 1993 and 2000 the US was able to convince other G-7 members of the Bank to vote against loans to Iran, but in 2000 this coalition against Iran dissolved, leading to a flurry of Congressional action and complaints about World Bank aid to Iran (Kirk 2007; Weiss and Sanford 2008). Members of Congress have gone so far as to create a World Bank Caucus, designed in part to extend greater oversight and control over it (Wroughton 2008). These examples suggest the important role that "control" plays in the politics of multilateral aid. We thus hypothesize that opposition to multilateralism will reflect this concern with loss of control over policy.

The third step in our argument focuses on the structure of preferences. The structure of preferences among principals and agents should determine the nature and extent of multilateralism chosen (Pollack 2003; Tallberg 2002). We focus on the PA problem in one country where the multiple principals are different domestic actors who are involved in the decision to delegate. The closer the principals' preferences are to the agent, the more extensive delegation usually is because control issues are muted (Epstein and O'Halloran 1999). The benefits of burden sharing and the costs of the loss of control over foreign policy thus vary for different principals, in our case then for different domestic actors. Opposition to multilateralism is likely to arise from domestic actors (i.e., those principals) whose preferences are farthest from those of 
the international institution, since delegation gives the institution (i.e., the agent) some latitude to pursue its own goals. All principals prefer an agent who has preferences identical to theirs since the loss of control is then inconsequential. But if principals - domestically or internationally - have divergent preferences, then one must expect contestation over delegation (Hawkins et al. 2006).

Support and opposition to multilateralism should thus depend on the structure of preferences on an issue. We expect to find the public and elites divided over multilateralism as a result of their differential concerns over control. We assume that the president largely sets bilateral aid policy. Hence the principals have a choice between this bilateral policy, which is close to the president's ideal point, or the international institution's policy, which is some combination of its members' preferences. The costs of delegating will be lower and the benefits higher when a domestic group's most preferred foreign policy (its "ideal point") is closer to that of the international agent-in this case, the multilateral institution responsible for coordinating policy. As the preferences of the domestic group depart from those of the institution's, the costs of delegation rise, because the resulting policies will not reflect what the group prefers. The bilateral policy alternative, which is close to the president's ideal point, will also matter. The further a group's preferences are from the international institution's and the closer they are to the bilateral alternative, the costlier multilateralism will be. Studies of delegation in the US domestic context focus heavily on the partisan divide (Epstein and O'Halloran 1999; Huber and Shipan 2002). Research suggests that a similar partisan divide may affect foreign policy, especially in terms of foreign aid goals. ${ }^{8}$

While Republicans and Democrats tend to have different levels of support for aidgiving in general, even when both support aid they do so in order to achieve different goals. Research points out that liberals in the US prefer that foreign aid promote economic development, while conservatives prefer that aid be used to advance US geopolitical or commercial interests. Fleck and Kilby (2006b) show that during periods of Republican control of Congress, foreign aid programs were driven heavily by commercial interests. When Democrats controlled the presidency and Congress, development concerns governed aid allocation more than when the Congress and/or presidency were controlled by Republicans. Also, congressional voting on aid shows that geopolitical interests in aid giving were weighted more heavily with a Republican president than a Democratic one (Milner and Tingley 2010).

The 2004 US National Leaders survey of political elites provides more evidence for this partisan divide: it shows greater support among liberals for helping poor countries improve their standards of living, whereas conservatives demonstrated greater support than liberals for providing military aid (Chicago Council 2005). Elite and general public opinion polls by the Chicago Council on Foreign Relations since the 1970s show that conservatives have tended to prefer a foreign policy more oriented towards security goals and the protection of allies than do liberals, but that liberals relative to conservatives prefer a policy oriented more towards improving the standard of living in poor countries. Finally, State of the Union speeches during the

\footnotetext{
${ }^{8}$ A general finding in the public opinion literature is that attitudes toward multilateralism break down along liberal-conservative lines, but little theoretical reason is given for this opposition to multilateralism per se (Broz 2008; Holsti 2004).
} 
Bill Clinton and George W. Bush administrations show that they differed in their commitment to multilateral organizations, with Republicans being much less favorable (Busby and Monten 2008). Hence even when liberals and conservatives agree on the need to give aid, they do not agree on the goals for aid-giving.

This partisan divide on the goals of aid policy affects the choice for multilateralism because the multilateral agencies have their own preferences for aid policy. Most multilateral institutions coordinating aid policy promote economic development goals for aid recipients first and foremost; they have less concern for the geopolitical or domestic commercial goals of their principals. The World Bank's attention to development, in contrast to the strategic and commercial opportunities afforded by bilateral aid, suggests that Democratic aid policy preferences are closer to those of the World Bank than are those of Republicans. ${ }^{9}$ Because their preferences are closer to those of the agent, the costs of delegating policy will be lower for liberals than for conservatives and hence they will be more eager to delegate. The greater divergences in aid preferences between the World Bank and conservatives in the US helps explain why they might worry more about loss of control in delegation to the Bank. The alternative to multilateral aid provision is allowing US aid to be allocated by US agencies such as USAID, the State Department and the Millennium Challenge Corporation (MCC). We assume here that these agencies' choices about aid are heavily influenced by the President, although Congress surely plays a role as well. Hence if the preferences of a principal are closer to those of the President's (or to the majority party in Congress) than to those of the international institution giving aid, then they should prefer bilateral aid. Domestic divisions thus should play a role in explaining support for and opposition to multilateralism if PA models have traction. Partisan divisions over multilateralism that we see in political elites should be reflected in public attitudes.

The principal-agent logic thus produces a series of hypotheses that we seek to test. We hypothesize that 1) political elites and the public should be divided over multilateralism and 2) the main reasons given for these differences should involve preferences for control relative to burden sharing. In addition, we hypothesize that 3 ) conservatives should be more opposed to delegation to an international institution like the World Bank and much more concerned with the loss of control in aid policy than liberals. We test these predictions from the PA model using public and elite opinion. Finally, we anticipate that 4) if we vary the preferences of the President, who largely sets bilateral policy, we should see changes in the preferences of respondents toward multilateral or bilateral policy. This last proposition we test in our survey experiment.

\section{Survey Data}

In this section we proceed as follows. First, we provide a basic overview of support for multilateralism from our various surveys. Next, we analyze the correlates of support for multilateralism, focusing on the role of political ideology. We then examine the reasons people give for supporting bilateralism versus multilateralism.

\footnotetext{
${ }^{9}$ Clist (2011) demonstrates that US bilateral economic aid has been highly influenced by geostrategic concerns.
} 
In these sections we consider samples of both the mass public and elites. Finally, to further test the claims deriving from the PA model, we provide an analysis of who cites "control" as a main reason for preferring bilateralism, and we examine the determinants of general attitudes toward the World Bank, the key multilateral aid institution. This section then examines the three core hypotheses from the PA model stated above.

While the choice of multilateralism is made by foreign policy elites, these elites are to some extent constrained by public attitudes but are also able to shape those attitudes. We then expect to see elite views and debates reflected in public opinion. We do not take a stance on which is causally prior; elite and public attitudes are deeply intertwined. Public opinion surveys allow us to examine general preferences for multilateralism as well as to explore reasons for these preferences; they are not ideal for understanding the sources of these preferences. We do not think the public has highly sophisticated views on foreign aid and we do not expect them to necessarily understand principal-agent theory. But we seek to explore whether their beliefs as expressed in a fairly simple survey are consistent with the hypotheses from principal-agent theory.

Our analysis employs data from several national surveys. A November 2000 Program on International Policy Attitudes (PIPA) survey asked individuals about their preferences for sending aid bilaterally or multilaterally (PIPA 2001). These questions allow us to directly investigate the choice for multilateralism versus a bilateral alternative. The next set of surveys were designed by the authors and fielded by the professional survey firm Polimetrix/YouGov. This firm delivers surveys through the internet and uses a custom weighting algorithm to produce survey weights to make the survey nationally representative. ${ }^{10}$ A wide variety of scholars in different sub-fields of political science have used this firm to produce data for their publications. We fielded these surveys in the summer and fall of 2008, the fall of 2009 , and the fall of 2010. Throughout we use supplied survey weights to create a nationally representative sample, though our results change relatively little if we do not use these weights. In these surveys we asked about preferences for multilateral versus bilateral aid. However, in the fall 2008 and following surveys we also elicited the reasons for preferring multilateral or bilateral aid. These reasons let us explore how members of the public think about the choice of multilateralism, and we expect these attitudes to be related to elite debates and views. To the extent that stated reasons correspond with those hypothesized in our theoretical model, we should have more confidence in the model. We also explore elite attitudes by focusing on subsamples of the public that have characteristics similar to policy elites as well as a new survey of international relations scholars. ${ }^{11}$

We first examine a subset of the respondents in all of our surveys, who correspond more closely to the American elite. Second, several of our questions were fielded in the 2011 Teaching, Research, and Policy View of International Relations Faculty (Maliniak et al. 2012). This sample of faculty teaching IR in American universities is

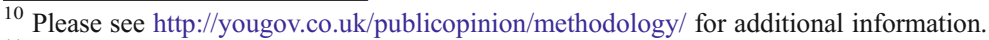

${ }^{11}$ Identifying elites is difficult, and scholars do not agree on this. Surveys of elites often identify them by their formal positions; see, for example, Hooghe (2003) and Chicago Council on Foreign Relations surveys of elites.
} 
by no means a representative one, and unsurprisingly is much more liberal than our other samples, thus leading us to expect higher levels of support for multilateralism.

\subsection{Overview of Support for Multilateralism}

Our first hypothesis is a simple one asking whether the public is divided over the value of multilateralism. To address this, we describe the levels of support for multilateralism in aid delivery. As noted, the design of the PIPA and our surveys differ. In the PIPA survey, support for multilateralism was measured with the following question:

I'm going to read you two statements. Please tell me which one you agree with more. [Random alternate order] A. When giving foreign aid, it is best for the US to participate in international efforts, such as through the UN. This way it is more likely that other countries will do their fair share and that these efforts will be better coordinated. B. When giving foreign aid it is best for the US to do so on its own because that way the US has more control over how the money is spent and will get more credit and influence in the country receiving the aid.

In the 2000 sample, $59 \%$ of respondents selected statement A, the multilateral option, while $41 \%$ selected statement B, the bilateral option. Authors of the survey interpreted this as indicating that the US public is more multilaterally oriented than was commonly perceived (PIPA 2001), though the public was still clearly divided. Interestingly, the PIPA questions were already framed to emphasize burden sharing and control considerations, not alternative arguments. Presumably PIPA wanted to design an ecologically valid survey, and their evocation of burden sharing and control considerations reinforces the PA hypotheses.

In our YouGov surveys, we asked about multilateral preferences in a different way. We used a very simple question to probe public attitudes since we did not expect them to be highly sophisticated and hence we tried to avoid priming their responses. We avoided the PIPA wording for two reasons. First, by using a different phrasing we could see whether covariates, like ideology, have a consistent effect irrespective of how questions are asked. Second, we were interested in the reasons people might have for supporting multilateralism or bilateralism, and hence did not want to include such reasons as part of the survey question. Our surveys instead asked:

"Would you prefer that the U.S. give economic aid directly to a country or give aid to an international organization (such as the World Bank or International Monetary Fund) which then would give it to the country?"

Using this question, we found weaker support for multilateralism. ${ }^{12}$ This weaker support might be anticipated since we did not prime the respondents with the benefits of multilateralism and may have made it seem as if one more layer of bureaucracy

\footnotetext{
$\overline{12}$ Alternatively, one might have asked this question by permitting a more continuous tradeoff or even no tradeoff at all between the two options. Asking the public what percent of aid should be multilateral seems to be a very hard question that we doubt many would have stable answers to. Asking just about multilateralism without any tradeoff seems likely to overestimate support for it since it now seems costless. We asked the question the way we did because it is a simple way to understand basic preferences for multilateralism versus bilateralism. Future surveys could ask the question in different ways.
} 
was involved. But what is notable is that the public in all the surveys is quite divided on multilateralism. In our summer 2008 survey, respondents chose between the multilateral $(20 \%)$, bilateral $(50 \%)$, and "do not know" options $(30 \%) .{ }^{13}$ For our fall 2008 and fall 2009 surveys, we excluded the "do not know" option. ${ }^{14}$ In the fall of 2008, $66 \%$ of respondents chose bilateral delivery, whereas $34 \%$ chose the multilateral option. In the fall of 2009 support for the multilateral option was even lower, with $73 \%$ preferring the bilateral option and $27 \%$ multilateral delivery. In 2010 we allowed a "don't know" response, but then asked a follow up requesting that one option be chosen. Excluding subjects with initial "don't know" responses, 78 \% preferred bilateral and $22 \%$ multilateral delivery. Table 1 presents summary information for each of our surveys.

Some may argue that theories of multilateralism apply more to foreign policy elites than to the public in general. Unfortunately, existing Council on Foreign Relations surveys of elites do not ask questions like ours. While there is no well-accepted definition of what segments of the public most resemble elites, as a rough proxy we also conducted analyses where we split our sample by college education. Individuals in our sample that share characteristics with the elite (e.g., college education) exhibit a similar set of preferences to the public as a whole.

We found that better educated individuals, who seem most similar to elites, have similarly weak levels of support for multilateralism, as does the overall public. In 2008, around $68 \%$ favored bilateralism, and only $32 \%$ preferred multilateralism. In 2009 and 2010, roughly $72 \%$ favored bilateral policies over $28 \%$ for multilateral ones. ${ }^{15}$ However, one type of elite, American International Relations professors in the TRIP survey, was more supportive of multilateralism. This is likely because on average these individuals are much more liberal than their non-academic elite counterparts. Interestingly, all of our surveys reveal the absence of a strong consensus on the choice for multilateralism. While the magnitudes of support for each option differ, there is no resounding consensus in support of multilateralism. Our discussion of the PA model suggests that differences in concerns over control of aid policy, which should be reflected in partisan ideological differences, might explain differences in preferences over multilateralism.

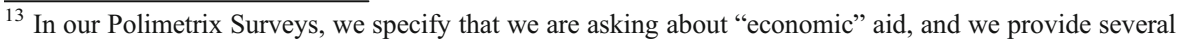
examples of non-UN international organizations through which some form of multilateral support is provided. These differences might explain the higher levels of support for multilateralism in the PIPA survey. An alternative explanation is that our questions made aid seem strictly as unconditional budgetary support. If citizens simply see multilaterals as adding an additional administrative cost beyond what a bilateral delivery will entail, which may or may not be the case, this will drive support down. The crucial point is that there are substantial divisions on this issue.

${ }^{14}$ We did this for several reasons. First, the political opinion literature is divided on how best to deal with the fact that people might not have clear, salient positions (Mondak 2001). We cover both cases. The results reported below differ relatively little in terms of the influence of important subject-level covariates. Second, in the fall 2008 and 2009 surveys, we asked follow up questions on why the individual preferred one channel of aid versus the other. In order to maximize responses to this question, we did not include a "don't know" response. The 2010 survey permitted "don't know" responses but then asked a follow up. While various branching methods might also be used, we feel our approach casts a broad, agnostic survey net.

${ }^{15}$ Similar patterns hold for less educated individuals.
} 
Table 1 Preferences for bilateral versus multilateral delivery of aid by survey

\begin{tabular}{|c|c|c|c|c|}
\hline & Bilateral & Multilateral & Don't know & $\mathrm{N}$ \\
\hline PIPA 2000 & $41.00 \%$ & $59.00 \%$ & & 577 \\
\hline YouGov summer 2008 & $50.19 \%$ & $19.06 \%$ & $30.75 \%$ & 2650 \\
\hline YouGov fall 2008 & $66.40 \%$ & $33.60 \%$ & & 979 \\
\hline YouGov fall 2009 & $73.44 \%$ & $26.56 \%$ & & 1500 \\
\hline YouGov fall 2010 (DK excluded) & $77.90 \%$ & $22.10 \%$ & & 759 \\
\hline YouGov fall 2010 (DK included) & $53.28 \%$ & $15.11 \%$ & $31.60 \%$ & 995 \\
\hline YouGov fall 2010 (DK follow-up) & $72.25 \%$ & $27.75 \%$ & & 989 \\
\hline TRIPS 2011 & $44.52 \%$ & $55.48 \%$ & & 1058 \\
\hline
\end{tabular}

Percent of respondents preferring bilateral versus multilateral aid for each survey. Percentages use survey weights for the PIPA and YouGov samples. In 2010 we asked the question allowing for a don't know response, but then in a follow-up question asked all those stating don't know to give their best guess

\subsection{Ideology and the Correlates of Multilateralism}

The public and our elites are divided in their support for multilateralism, giving some support to the PA model. But what are the correlates of support for multilateralism, and is support for multilateralism divided along ideological lines, as the PA model anticipates?

We code responses of the individuals who prefer sending aid multilaterally as a 1 and bilaterally as a 0 . We exclude respondents in the summer 2008 and 2010 survey if they answered "don't know," though the results do not substantively change if we include everyone in the 2010 survey. To measure political ideology in our surveys and the PIPA survey, we use a standard five-point liberal-conservative scale, Ideology, with strong liberals coded 0 and strong conservatives coded 4 . The TRIP survey asked two 7-point liberal-conservative questions on social and economic issues. Both questions were highly correlated, and we simply sum the measures and divide by 2 .

We estimate separate models for each survey to allow for differences across the surveys and present results in Table 2. Each model uses a probit regression model with robust standard errors. All models, except the TRIP survey, use survey weights to approximate a nationally representative sample. We estimate models including only the Ideology variable as well as models with a set of control variables when available.

Our set of control variables are those that often appear in other models of public opinion in foreign affairs (Chittick et al. 1995; Holsti and Rosenau 1984, 1986). The exact set of controls depends on their availability in the survey. In our setting there are not necessarily clear directional predictions for these variables, and thus we estimate models with and without these variables. To control for general preferences for international engagement versus isolationism, we asked respondents whether they support or oppose the US taking an active role in world affairs, ActiveRole. ${ }^{16}$

\footnotetext{
16 The question read: "Please tell us whether you strongly agree, somewhat agree, somewhat disagree or strongly disagree with the following statement: The U.S. needs to play an active role in solving conflicts around the world" (Mansfield and Mutz 2009).
} 


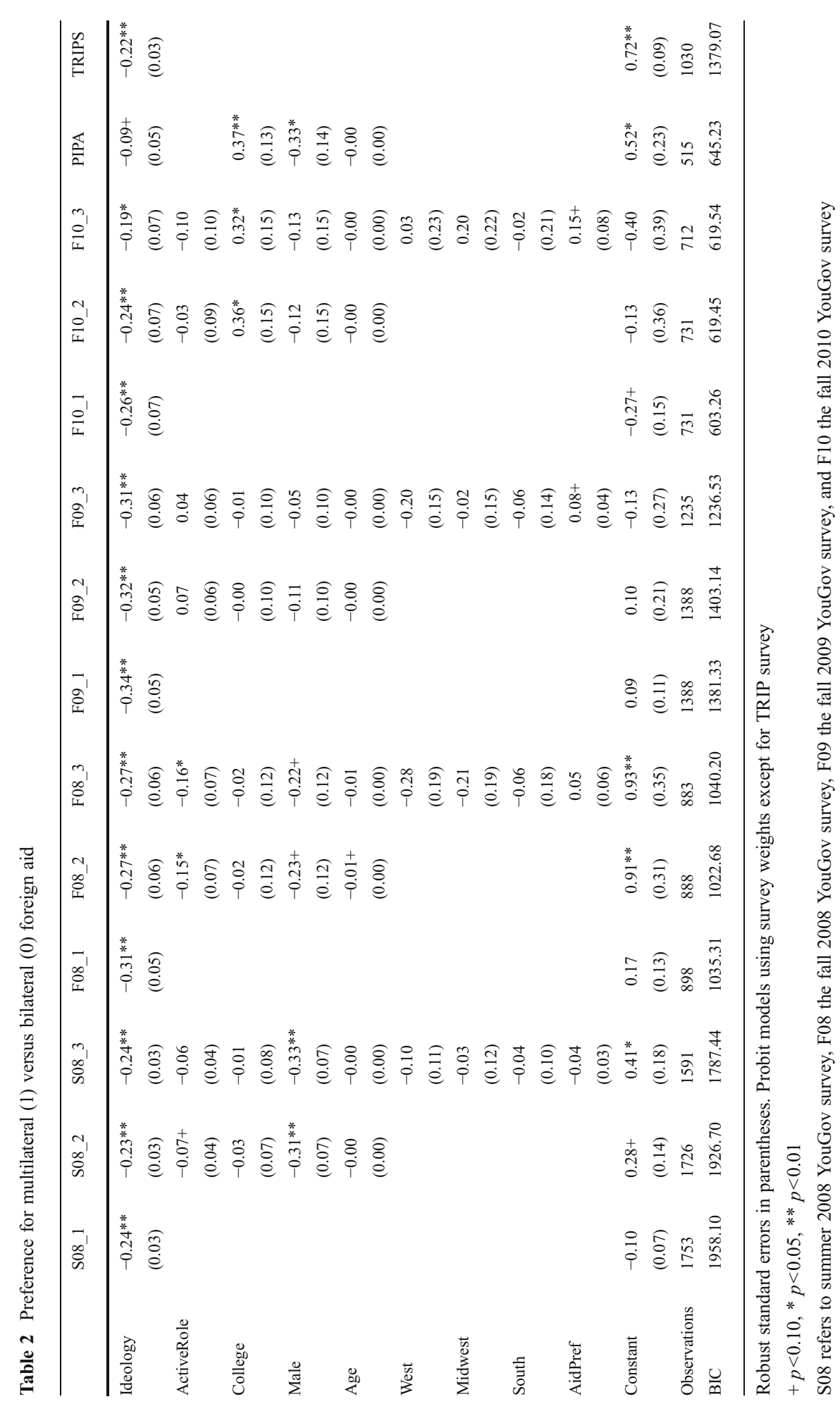


Individuals preferring an active role in world affairs may prefer using multilateral institutions because it represents a deeper type of international commitment. We also include variables for gender, Male (1 if male, 0 if female), Age (continuous in years), and whether someone achieved a 4-year college degree or greater (1) or has less education (0), labeled College. Individuals with higher education may prefer engagement with international institutions if they are more aware of arguments about the relative effectiveness of these institutions. We also estimate models with controls for the respondent's region (dummy variables for the South, Midwest, and West) as earlier work identifies regional differences in foreign policy attitudes (Trubowitz 1992). Finally, we control for a respondent's preferences for increasing or decreasing US economic aid (AidPref). ${ }^{17}$ Preferences about the overall amount of aid that should be given might affect the choice for multilateralism. Additional, unreported models also controlled for whether or not the respondent owns a passport, had taken an economics class, or was interested in the news. Including or excluding these controls does not significantly change our inferences about the role of political ideology.

The effect of political ideology was uniformly negative across the models and surveys: individuals who are more conservative tend to oppose multilateralism, and those who are more liberal support sending aid through multilateral institutions. In our online appendix, ${ }^{18}$ we report simple differences in the proportion of self-identified Democrats and Republicans preferring multilateralism. These differences were always highly significant. The relationship between ideology and support for multilateralism is highly significant across all of the models and produces large substantive effects. For example, using the second model from the 2009 survey, changing ideology from "very liberal" to "very conservative," while holding age at the sample median and other covariates at 0 (female, no college, Northeast, anti-internationalist), decreased the probability of preferring multilateralism by $42 \%$ (95 \% CI: 52, $32 \%)$. Furthermore, controlling for general aid preferences did not substantially change the influence of ideology. An individual's preferences about levels of aid giving do not seem to consistently affect their preferences for multilateralism. The influence of the AidPref variable was marginally significant in the 2009 and 2010 surveys but not in the spring and fall 2008 surveys. The more consistent finding is, as the PA model suggests, that the divergence in preferences about the goals of aid (once levels are chosen) drives concerns about handing over policy to an international institution. The other variables in the model were either insignificant or inconsistently estimated. ${ }^{19}$

\footnotetext{
${ }^{17}$ We measure preferences towards aid in general with the following question asked prior to questions about multilateralism and separated by a series of non-foreign aid related questions. "The United States gives various types of foreign aid to other countries. Some of this aid is economic aid that is designed to promote economic development and welfare in poor countries. Other aid is military aid such as military hardware and training. Other aid is disaster relief. What should the U.S. do with its foreign economic aid program? Expand a lot, expand a little, keep the same, decrease a little, decrease a lot."

${ }_{18}^{18}$ Available on the journal website.

${ }^{19}$ The effect of international orientation was ambiguous. Those wanting the US to take a more active role in world affairs were not more likely to support multilateralism.
} 
If members of the public receive cues from elites, and these cues divide along partisan lines, then we would suspect that members of the public might also know which parties are more likely to oppose multilateral aid. To probe this possibility, we asked a follow-up question in our 2010 survey. "Some have said that Democrats and Republicans generally disagree about whether to send economic aid bilaterally (directly to a country) or multilaterally (through an international organization that many countries belong to). Which party do you think opposes giving foreign aid through multilateral organizations the most?" In our sample $70 \%$ of respondents said that Republicans most oppose giving aid multilaterally and $30 \%$ named Democrats. Not surprisingly, this split increases to $85 \% / 15 \%$ when we only include respondents with a college education. This result is consistent with both views of the relationship between public and elite opinion: either that elites shape public attitudes or that public opinion constrains elite opinion. A more definitive test of the causal relationship is beyond the scope of the current paper, which focuses more generally on the politics of delegation.

In section 2 above, we presented strong evidence suggesting that political leaders divide along partisan lines and repeatedly discuss multilateralism in principal-agent terms. In the online appendix, we present similar regression models but on the subsample of the population that most resembles the elite. We find that ideology is negative and significant in our 2008 and 2009 surveys, implying that elites are divided along partisan lines just like the general public. In each year except 2009, there was no significant difference in the effect of ideology between college and noncollege educated respondents. Furthermore, the respondents in the TRIP survey confirm this partisan inclination: the stronger support for multilateralism in this survey reflects the fact that TRIP respondents, who are all college-educated academics, are heavily more liberal. And as shown in Table 2, the effect of ideology is significant in this sample of scholars as well. Ideology, as it reflects the preferences of principals vis-à-vis the international agent, then is the leading correlate of support for multilateralism.

\subsection{Rationales for Multilateralism vs. Bilateralism}

This section explores our second hypothesis about multilateralism, focusing on the reasons that individuals give for their preferences. Hypotheses derived from the principal-agent model imply that support for multilateralism should be predicated on burden sharing and support for bilateralism based on the desire to control aid policy. We are interested in seeing how prevalent these PA reasons for the two choices are. Undoubtedly the public and elites also possess other reasons for their choice between these two, but we want to see which reasons resonate the most.

In looking at the reasons for multilateral support, there are at least two other explanations we need to take into account. These reasons are not mutually exclusive with the PA ones; indeed, we asked respondents to give us their top two choices to see which seemed more salient. One account of why countries choose multilateralism relies on the calculations of the strongest country. In this view, the hegemon, the world's strongest power, chooses multilateralism as a form of self-constraint that allows it to signal to other countries that it will not 
abuse its position if the others participate in a joint adventure. As Lake argues, "dominant states must demonstrate that they cannot or will not abuse the authority that subordinates have entrusted to them...Some mechanism of restricting opportunism by dominant states is necessary. This requires that dominant states tie their hands, giving up policies or options they would have otherwise enjoyed, or send costly signals of their benign intent or willingness to act only within the bounds of what their subordinates regard as legitimate... Multilateralism has been a key signaling mechanism for the US since 1945" (Lake 2009, pg. 14). Similarly, others such as Cowhey (1993), Ikenberry (2001) and Deudney (2007) have posited that the US has used multilateralism to self-bind and restrain its power since World War II.

Another approach focuses on the power of norms to guide state behavior, suggesting that governments choose multilateralism because it is widely considered to be the appropriate way to engage. Elite beliefs in the normative appropriateness of multilateralism should be reflected in public attitudes. Global norms help support a policy of multilateral interaction with other states (Finnemore 1996a; Ruggie 1993). As Finnemore notes, "At a systemic level, norms among states can also create shared expectations for multilateralism" (1996b, pg. 145). Similarly, Ruggie makes the case that it was the spread of American norms about appropriate international cooperative behavior that led to the development of multilateralism after World War II (1993, pg. 306). ${ }^{20}$ The legitimacy of US foreign policy, in this view, depends on following the norm of multilateralism. Adopting a unilateral policy brings with it additional costs associated with a lack of legitimacy because it suggests that states violate global norms to serve their own interests (Finnemore 1996a, pg. 183). Furthermore, multilateralism is viewed an accepted way of conducting foreign policy that is seen as legitimate domestically because it is so closely tied to the national identity of Western democracies who possess shared norms and values (Risse-Kappen 1996, pg. 378).

If the normative argument is correct, then we expect to see individuals reporting that they support multilateralism because they believe that multilateral engagement by the US is more legitimate and demonstrates shared motives with other nations. If the self-constraint argument is correct, then support for multilateralism should be based upon a belief that multilateralism locks the US more solidly into its international commitments. We expect concerns over control to animate public support for bilateralism, and desires for burden sharing to foster support for multilateralism in the PA model. Different theories of multilateralism should evoke different reasons in the minds of elites and publics. These theories need not be alternatives; individuals could believe all of them, and parts of the American public could believe some more than others. We cast our reasons so that individuals had to list their top two choices, thus giving us their ranking. Our interest is in how prevalent these different reasons are among the public and elites.

\footnotetext{
${ }^{20}$ For instance, the development of the idea of a "Western security community" has been associated with the continuity of the norm of multilateralism among Western countries even after the end of the Cold War (Jepperson et al. 1996, pg. 64).
} 
Following their indication of preference for multilateral versus bilateral aid, we gave subjects a list of candidate reasons. ${ }^{21}$ If subjects indicated that they prefer aid to be delivered bilaterally, then the reasons we provided were:

- This means that the US controls the economic aid and that other countries cannot influence how it is used. (PA model)

- This gives the US the most flexibility.

- This sends a message to countries receiving aid from the US that the US has strong convictions.

- This sends a message to other countries - countries not receiving aid that the US does not have good relations with - that the US is more serious/determined to achieve their goals.

- It is harder for multilateral aid agencies to be monitored by US organizations.

- Other

If subjects chose multilateral aid, they were given the following response options:

- This involves sharing the costs of economic aid with partner countries. (PA model)

- 2008/2009 This locks the US into its international commitment more solidly. (Self-binding)

- 2010 This locks the US into its international commitment more solidly and reassures other countries about the US' intentions. (Self-binding)

- This sends a message to countries receiving aid that the US's motives are widely shared. (Normative)

- This sends a message to other countries - countries not receiving aid that the US does not have good relations with - that its partners are more serious/determined to achieve their goals.

- Multilateral aid agencies are monitored by more organizations around the world.

- Multilaterals prevent the US government from using aid for things other than economic development.

- Other

Respondents chose the first and second most salient reason. What do our respondents say is the reason(s) for their preference over multilateralism in foreign aid? Table 3 breaks out the response frequencies for each of the surveys and lists both the first and second most important reason. ${ }^{22}$ The frequencies provided here utilize survey weights when available, but dropping them changes little.

The most prevalent reason individuals prefer giving aid bilaterally versus multilaterally is because it means that the US has more control over the aid. The vast

\footnotetext{
${ }^{21}$ Future work could use only open-ended responses or use deliberative polling procedures, although both have weaknesses. Other theories beyond the self-binding and normative accounts might give other reasons for bilateral aid that we do not list. Below we report the percentage of people choosing the "other" category, which is low. Following a suggestion from David Lake we changed the self-binding prompt for the 2010 survey, which as discussed below increased support for this rationale but not beyond that of burden sharing. ${ }^{22}$ In the 2008 and 2009 surveys the order of the questions was fixed and in 2010 the order was randomized. In 2010 the self-binding rationale also included the phrase "and reassures other countries about the US' good intentions."
} 
Table 3 Frequency of reasons for multilateral or bilateral aid preferences. Percentages use survey weights when available

\begin{tabular}{|c|c|c|c|c|c|c|c|c|}
\hline & \multicolumn{2}{|c|}{ YouGov 2008} & \multicolumn{2}{|c|}{ YouGov 2009} & \multicolumn{2}{|c|}{ YouGov 2010} & \multicolumn{2}{|c|}{ TRIP- 2012} \\
\hline & $\begin{array}{l}\text { 1st } \\
\text { choice }\end{array}$ & $\begin{array}{l}\text { 2nd } \\
\text { choice }\end{array}$ & $\begin{array}{l}1 \mathrm{st} \\
\text { choice }\end{array}$ & $\begin{array}{l}\text { 2nd } \\
\text { choice }\end{array}$ & $\begin{array}{l}\text { 1st } \\
\text { choice }\end{array}$ & $\begin{array}{l}\text { 2nd } \\
\text { choice }\end{array}$ & $\begin{array}{l}1 \text { st } \\
\text { choice }\end{array}$ & $\begin{array}{l}\text { 2nd } \\
\text { choice }\end{array}$ \\
\hline \multicolumn{9}{|l|}{ Bilateral reasons } \\
\hline US control & $48.70 \%$ & $18.64 \%$ & $48.70 \%$ & $18.64 \%$ & $43.59 \%$ & $24.83 \%$ & $31.47 \%$ & $14.22 \%$ \\
\hline US flexibility & $14.77 \%$ & $23.32 \%$ & $14.77 \%$ & $23.32 \%$ & $19.36 \%$ & $21.07 \%$ & $31.93 \%$ & $27.97 \%$ \\
\hline Message of strong US convictions & $12.15 \%$ & $16.94 \%$ & $12.15 \%$ & $16.94 \%$ & $15.78 \%$ & $20.08 \%$ & $9.79 \%$ & $15.62 \%$ \\
\hline Message to achieve US goals & $5.77 \%$ & $11.28 \%$ & $5.77 \%$ & $611.28 \%$ & $7.19 \%$ & $10.03 \%$ & $3.26 \%$ & $8.39 \%$ \\
\hline Hard to monitor multilat agencies & $15.85 \%$ & $23.47 \%$ & $15.85 \%$ & $23.47 \%$ & $12.82 \%$ & $17.99 \%$ & $13.52 \%$ & $20.75 \%$ \\
\hline Other & $2.76 \%$ & $6.34 \%$ & $2.76 \%$ & $6.34 \%$ & $1.25 \%$ & $6.00 \%$ & $10.02 \%$ & $6.76 \%$ \\
\hline \multicolumn{9}{|l|}{ Multilateral reasons } \\
\hline Sharing costs of aid & $32.35 \%$ & $19.84 \%$ & $37.60 \%$ & $13.06 \%$ & $18.54 \%$ & $22.02 \%$ & $13.82 \%$ & $12.75 \%$ \\
\hline Locks in commitment & $14.02 \%$ & $6.52 \%$ & $8.12 \%$ & $69.84 \%$ & $18.01 \%$ & $16.26 \%$ & $26.57 \%$ & $619.93 \%$ \\
\hline Message of widely shared motives & $7.82 \%$ & $21.17 \%$ & $17.23 \%$ & $023.41 \%$ & $17.14 \%$ & $16.52 \%$ & $11.85 \%$ & $20.29 \%$ \\
\hline Message to non-recipients & $3.98 \%$ & $4.20 \%$ & $2.44 \%$ & $5.84 \%$ & $9.01 \%$ & $12.70 \%$ & $1.62 \%$ & $6.39 \%$ \\
\hline Multilat agencies are monitored & $18.07 \%$ & $28.06 \%$ & $17.78 \%$ & $21.44 \%$ & $19.89 \%$ & $17.57 \%$ & $13.11 \%$ & $12.57 \%$ \\
\hline Multilats use aid for development & $19.87 \%$ & $14.26 \%$ & $12.28 \%$ & $21.68 \%$ & $14.42 \%$ & $9.53 \%$ & $28.55 \%$ & $22.80 \%$ \\
\hline Other & $3.90 \%$ & $5.96 \%$ & $4.55 \%$ & $0 \quad 4.74 \%$ & $2.99 \%$ & $5.39 \%$ & $4.49 \%$ & $0 \quad 1.97 \%$ \\
\hline
\end{tabular}

majority of respondents indicated that considerations of control were the most salient. This is consistent with the logic of the principal-agent model. The perils of multilateralism are that it entails using an agent who might have its own preferences or be under the influence of other principals. Hence concern over the desire to retain control is paramount in the preference for bilateralism. ${ }^{23}$ The normative and selfconstraint models do not make clear predictions about why respondents would support bilateralism; hence, we must turn to those who prefer multilateralism to see if rationales consistent with those theories are present.

The most frequent reason given by our survey respondents in the 2008 (32\%) and 2009 (38 \%) surveys for supporting multilateral delivery of aid was that the costs would be shared with other countries. In 2010 burden sharing still was prominent $(18 \%)$, but here we found more support for other rationales. The normative and selfbinding models receive less support in these analyses for 2008 and 2009, but greater support in 2010. The normative model suggests that people should prefer multilateralism because it "sends a message to countries receiving aid that the US's motives are widely shared." 24 About $8 \%, 17 \%$, and $17 \%$ of individuals in 2008, 2009, and 2010

\footnotetext{
$\overline{23}$ And in Table 4, as discussed below, we show that this reason was most salient among conservatives as our PA model anticipates.

${ }^{24}$ We think that the idea of widely shared motives among countries gets at a central idea in normative accounts - i.e., the idea of a shared norm of using multilaterals. But the question does not ask directly if the multilateralism is "appropriate" and "motives" may be too close to "interests." Future work could use different phrasings.
} 
respectively, mentioned this as their first reason, and $21 \%, 23 \%$, and $17 \%$ mentioned this as their second most important reason for preferring multilateralism. If the self-binding argument is correct, we expect that individuals should cite the fact that multilateralism "locks the US into its international commitments more solidly" as their primary reason for supporting it. In our data about $14 \%$ (2008) and $8 \%$ (2009) cite this as their number one reason, and $7 \%$ and $10 \%$ mention this as their second most important reason. In the 2010 survey there was more support for the self-binding (18\%) and normative (17\%) theories. In 2010 then there was more even support for all three sets of reasons. Even including explicit mentions of these other reasons, we find that a substantial portion of the public does seem to support multilateralism for reasons associated with the PA model.

Elites look somewhat similar to the public in their support for multilateralism. Breaking out our data once again by education reveals that those individuals in our sample most similar to elites espouse principal-agent based views of burden sharing and control. These individuals are divided along partisan lines on the choice for multilateralism; and the reasons they list for their preferences are similar to the full, nationally representative sample. ${ }^{25}$ Responses to the elite TRIP survey are less supportive of the burden sharing aspect of PA theory. This highly liberal and educated sample did not place much weight on burden sharing considerations. While advocates of bilateral aid stressed control as an important reason, flexibility considerations were also salient. As discussed below, while control was important in the TRIP survey, it might have been less important because conservatives put more weight on control and this sample was highly liberal. ${ }^{26}$

Overall, the salience of burden sharing and control concerns for our mass and elite respondents suggests support for the PA model, but among supporters of multilateralism burden sharing concerns do not provide an exclusive rationale. The different theories of multilateralism may not be exclusive and individuals may hold more than one set of reasons why they support or oppose multilateralism. Furthermore, the alternative theories we discuss do not offer competing rationales for bilateralism and so our ability to comparatively test the theories with bilateral responses is more limited. Our data do suggest, however, that the American public and elite is divided over the value of multilateralism; that concerns about control, especially among conservatives, dominate the reasons for preferring bilateralism; and that very frequently individuals who support multilateralism cite burden sharing as the reason.

\subsection{The Conditional Importance of Control: How the Structure of Preferences Matters}

In section 2, we claimed that the PA model also hypothesized conservatives should be more opposed to delegation to an international institution like the World Bank and much more concerned with the loss of control in aid policy than liberals. Here we explore those claims. PA theory expects that partisanship matters since it shapes one's preferences for the goals of aid policy. Principals whose preferences are further from

\footnotetext{
${ }^{25}$ Less educated members of the public also shared these concerns. Education levels did not differentiate the public.

${ }^{26}$ A minority of our respondents gave "other" responses. Some of these reasons are not included in our list, such that multilaterals are more efficient.
} 
the multilateral agencies' will be less willing to delegate; they will be much more concerned about control over the agent. This is especially true if bilateral policy is controlled by agents with preferences closer to the principals. Elsewhere scholars have shown that political ideology in the form of the left-right or DemocraticRepublican partisan divide in the US colors attitudes toward aid greatly (Lumsdaine 1993; Milner and Tingley 2010, 2011; Tingley 2010). As noted before, those on the right or in the Republican Party tend to prefer aid that is most closely tied to national security goals, not economic development or social ones. They worry that multilateral agencies will give aid to countries for development programs that do not necessarily enhance US national security. Furthermore, conservatives worry even more about control over US aid policy because they do not trust multilateral institutions to have the same national security interests as the US has. Conservatives thus have aid preferences closer to those of Republican presidents and further from those of most multilateral aid organizations (Fleck and Kilby 2006b; Milner and Tingley 2010).

To investigate whether the structure of domestic preferences affects the choice for multilateralism further, we conduct several analyses. First, throughout all of our surveys that asked for rationales, among individuals preferring bilateral aid, ideology strongly predicted whether or not a respondent cited control as a reason for their position. Table 4 reports, for each of our national surveys that asked for reasons of support, the bivariate relationship between citing control as a reason $(=1,0$ otherwise) and our measure of ideology (estimated using a probit model). Among those favoring bilateral aid, more conservative individuals are significantly more likely to say control over the policy is their primary reason. Additional controls such as education and gender do not change this relationship.

Second, we show that attitudes toward the main multilateral institution giving aid, the World Bank, correlate with ideological dispositions and these in turn correlate with concerns over control, as the PA model suggests. In the 2010 surveys, we asked respondents on a scale of 0-10 how "warm" they felt towards the World Bank (the multilateral institution in the survey question) prior to the other questions about aid. In Table 5 using a probit model, those who were more favorable toward the World

Table 4 Determinants of citing "Control" as reason for preferring bilateral aid

\begin{tabular}{lllllll}
\hline & F08_1 & F08_2 & F09_1 & F09_2 & F10_1 & F10_2 \\
\hline Ideology & $0.16^{* *}$ & $0.15^{* *}$ & $0.20^{* *}$ & $0.20^{* *}$ & $0.08+$ & $0.09^{*}$ \\
& $(0.05)$ & $(0.05)$ & $(0.04)$ & $(0.04)$ & $(0.04)$ & $(0.04)$ \\
College & & -0.09 & & 0.02 & & -0.15 \\
& & $(0.11)$ & & $(0.09)$ & & $(0.10)$ \\
Gender & & 0.05 & & 0.05 & & $-0.21^{*}$ \\
& & $(0.11)$ & & $(0.08)$ & & $(0.10)$ \\
Constant & 0.11 & 0.13 & 0.07 & 0.05 & 0.09 & $0.23+$ \\
& $(0.12)$ & $(0.14)$ & $(0.11)$ & $(0.12)$ & $(0.11)$ & $(0.13)$ \\
Observations & 628 & 628 & 1041 & 1041 & 643 & 643 \\
BIC & 793.09 & 805.17 & 1249.97 & 1263.46 & 869.78 & 875.67 \\
\hline
\end{tabular}

Robust standard errors in parentheses. Probit model used. $+p<.1, * p<.05, * * p<.01$ 
Table 5 Preference for multilateral aid as function of feelings towards World Bank amongst Republicans (model Multi, probit) and relationship between World Bank feelings ( $0-10$ scale) and citation of control as reason for preferring bilateral aid delivery (model WBFeel, OLS)

\begin{tabular}{lllllll}
\hline & Multi1 & Multi2 & Multi3 & WBFeel1 & WBFeel2 & WBFeel3 \\
\hline WorldBank feel & $0.14^{* *}$ & $0.14^{* *}$ & $0.11^{* *}$ & & & \\
& $(0.03)$ & $(0.03)$ & $(0.03)$ & & & \\
ControlReason & & & & $-0.45^{*}$ & $-0.41^{*}$ & -0.30 \\
& & & & $(0.21)$ & $(0.21)$ & $(0.20)$ \\
College & & 0.14 & 0.14 & & $0.55^{* *}$ & $0.45^{*}$ \\
& & $(0.12)$ & $(0.12)$ & & $(0.20)$ & $(0.20)$ \\
Gender & & -0.17 & -0.12 & & -0.29 & -0.01 \\
& & $(0.12)$ & $(0.12)$ & & $(0.20)$ & $(0.20)$ \\
Ideology & & & $-0.27^{* *}$ & & & $-0.59^{* *}$ \\
Constant & $-1.40^{* *}$ & $-1.35^{* *}$ & $-0.68^{* *}$ & $4.43^{* *}$ & $4.33^{* *}$ & $5.57^{* *}$ \\
& $(0.15)$ & $(0.16)$ & $(0.22)$ & $(0.17)$ & $(0.22)$ & $(0.27)$ \\
Observations & 589 & 589 & 573 & 497 & 497 & 483 \\
BIC & 628.19 & 637.69 & 600.59 & 2204.65 & 2208.07 & 2107.34 \\
\hline
\end{tabular}

Robust standard errors in parentheses, $+p<.1, * p<.05, * * p<.01$

Bank (WorldBank Feel) were more likely to favor multilateralism. ${ }^{27}$ And, using an OLS model, individuals citing control as a reason for preferring bilateralism (Control Reason), whether conservative or liberal, had significantly lower affinities towards the World Bank compared to individuals citing other reasons. This relationship holds in bivariate regressions in all three surveys. Once we introduce some controls, the tstatistic for the Control Reason variable slips to $a b s(t)=1.5$ in the 2010 survey. Their distaste for the Bank likely arises because of their differences over the goals of aid, and hence their concerns over control reflect these differences. The additional hypotheses from the PA model, which we spelled out in section 2, that conservatives should be more opposed to delegation to an international institution like the World Bank and much more concerned with the loss of control in aid policy than liberals are supported by our data.

\section{Survey Experiment}

In our final hypothesis from the PA model, we anticipated that if we vary the preferences of the President, who plays an important part in setting bilateral policy, we should see changes in the preferences of respondents toward multilateral or bilateral policy. This preference ordering is important for it underlines why control over aid policy is so important. Hence one potential implication of the PA theory is

\footnotetext{
27 This data does not let us identify the direction of causality. Do people like multilateralism because they like the World Bank, or the other way around? Experimental studies might let us answer these questions.
} 
that the salience of control will depend on whether a respondent has a political orientation more similar to an actor likely to shape bilateral aid policy, such as the President, or more similar to the multilateral institution. But these concerns should be tempered by who is in charge of the US executive branch. If Republicans control the presidency and have preferences far from the multilateral agent, then control should matter more since bilateral policy (in contrast to the international agent's) will be closer to that preferred by conservatives. We ask here whether there is evidence that concerns over control of policy can be manipulated by changing the partisanship of the president.

In our 2008 surveys we asked whether individuals would be more or less supportive of multilateral or bilateral aid, conditional on whether a Democrat (i.e., Obama) or a Republican (i.e., McCain) won the election. Is support for multilateralism increased when survey respondents are asked to consider that the Presidency will be held by the candidate whose preferences are far away from their own? ${ }^{28}$ Conversely, if respondents are asked to consider their preferred executive being in charge, then does bilateral aid become more attractive?

The timing of our fall 2008 survey was uniquely suited to answer these questions because it was fielded prior to the election of President Obama. In light of this, we embedded a small experimental manipulation in this survey. After eliciting preferences for multilateralism, their reasons and what candidate the respondent was most likely to vote for, we asked whether a respondent would like to change the amount of aid given multilaterally versus bilaterally conditional on one candidate winning in the election. Half of our respondents were asked the question after being told that McCain won and half with Obama winning. ${ }^{29}$ Respondents could say that they wanted to increase the multilateral share, increase the bilateral share, or keep the relative shares the same. No information was provided about the current shares. ${ }^{30}$

Our expectations are that McCain voters when told McCain is going to be president will prefer even more bilateral aid; and that Obama voters if told McCain will win prefer more multilateralism. The experiment provides strong support for the first part of that conjecture. Results are summarized in Table 6.

The key difference between the two treatments is for McCain voters. Under a McCain Presidency, there is overwhelming support among McCain voters for increasing the proportion of bilateral aid. In our sample, $63 \%$ of McCain voters of respondents who received the McCain treatment said they preferred to increase the proportion of aid sent bilaterally. Under the Obama treatment, only $38 \%$ of McCain voters supported moving more aid towards bilateral programs. This gap of $25 \%$ is

\footnotetext{
${ }^{28}$ For example, if multilateral institutions limit the ability of a particular partisan orientation to shape foreign policy, then multilateral aid can form a desirable constraining device.

${ }^{29}$ We believe this manipulation holds constant expectations about who would actually win. However, if this manipulation were not perfect then some subjects could have answered the questions conditional on their own expectations of who would win. While this might moderate the effect of our treatment, we did not ask a manipulation check question for our treatment given its rather direct/explicit nature and space considerations.

${ }^{30}$ The specific text of the question was: If [McCain/Obama] wins in November would you like the US to change how it delivers aid by: 1) Increasing the percentage of aid given through international organizations and decrease the amount given by the US directly 2) Increasing the percentage of aid given directly by the US and decrease the amount given through international organizations 3) Keeping the relative amounts of these ways of giving aid the same.
} 
Table 6 Changes in multilateral vs. bilateral allocation by partisan affiliation and randomly assigned winner of 2008 US Presidential election

\begin{tabular}{lcccc}
\hline & Obama wins & McCain wins & Absolute difference & t-statistic \\
\hline McCain voters & & & & \\
More bilateral & $38 \%$ & $63 \%$ & $25 \%$ & 4.42 \\
No change & $41 \%$ & $28 \%$ & $14 \%$ & 2.47 \\
More multilateral & $20 \%$ & $9 \%$ & $11 \%$ & 2.92 \\
Obama voters & & & & \\
More bilateral & $39 \%$ & $30 \%$ & $9 \%$ & 1.58 \\
No change & $30 \%$ & $44 \%$ & $5 \%$ & 2.42 \\
More multilateral & $32 \%$ & $27 \%$ & & 0.86 \\
\hline
\end{tabular}

statistically significant $(a b s(t)=4.4)$ and illustrates how support for bilateral aid is conditional on whether the executive shares policy preferences with the respondent. ${ }^{31}$ More McCain voters when told McCain would be president wanted to increase the share of bilateral aid. Among McCain voters, $41 \%$ of those when told Obama would be president wanted no changes compared to $28 \%$ when told McCain would be president $(a b s(t)=2.5)$. These McCain voters who supported the status quo (i.e., Bush's policies) may have viewed an increase in multilateralism as undesirable because their preferences were likely to be far from those of the multilateral institutions, and they may have opposed more bilateralism since Obama's administration would have controlled this policy. Finally, more McCain voters wanted aid to be more multilateral under an Obama presidency $(20 \%)$ versus only $9 \%$ in the McCain condition, a statistically different gap of $11 \%(a b s(t)=2.9)$. Thus the effect of the McCain treatment among McCain voters was to dramatically increase the percent of individuals suggesting a shift to bilateral aid, as we expected.

For Obama voters, $27 \%$ of those facing a McCain administration wanted to increase the ratio of multilateral aid, whereas $32 \%$ supported doing so when facing an Obama presidency, a difference of only 5 percentage points and not statistically significant from zero $(a b s(t)=.86)$. The change in support for increasing the bilateral aid portfolio among Obama voters was slightly higher in the Obama treatment (39\%) versus in the McCain treatment (30\%), a difference close to significance at the $p=.1$ level $(a b s(t)=1.58)$. Thus unlike McCain voters, the differences across the treatment conditions were more muted for Obama voters. It is possible that this is because the importance of control was lower for liberals rather than conservatives (see Table 4) since their preferences were closer to Obama's and those of the multilaterals. Future research could investigate this finding. But for conservative voters having a conservative president with preferences close to their own makes them want to maintain control over aid policy and not delegate it to an international institution, which would probably have preferences further away from theirs than their party's President.

Support for multilateralism thus is conditional on the congruence between the preferences of the respondent and the executive, who sets bilateral aid policy, relative to the international agent. If we use our subsample of elite respondents, we get very

${ }^{31}$ These tests use differences in proportions with survey weights included. 
similar results in the experiment, suggesting once again that the public reflects elite views. Our results suggest that this dynamic is most salient for respondents a priori less likely to support multilateralism: i.e., conservative voters. Thus our data show that the divergence in preferences among different domestic principals, the president who largely sets bilateral policy, and the multilateral agent are influencing attitudes toward multilateralism, as the PA model predicts.

Can a simpler partisanship story, without reference to a PA model, explain support and opposition to multilateralism? We doubt this since the ideological divisions that divide left from right in the US focus on the extent of government intervention in the market (McCarty et al. 2006), and the choice of multilateral versus bilateral aid provision does not fall along this divide. Aid provision is itself government intervention in the market, no matter whether it is by national or international agencies. Key to explaining the partisan divide over multilateralism is the degree of preference divergence over the goals of aid between the multilateral agency and domestic principals, namely conservatives versus liberals. The magnitude of this preference gap makes conservatives more opposed to multilateralism, not their dislike for aid. Our data show that attitudes toward aid overall do not consistently predict support or opposition to multilateralism across the surveys; furthermore, its effect is much more imprecisely estimated compared to that of the ideology variable. The preference divergence between principals and agents over the goals of aid policy, as highlighted by PA models, explains the partisan divide over multilateralism in the most consistent manner in our data. Those who view the World Bank with greater suspicion, whether conservative or liberal in orientation, for instance, cite concerns over control of aid more frequently and are more opposed to multilateralism.

\section{Conclusion}

The choice for multilateralism is an important one. Multilateral agencies have never received the majority of US aid funds. Our data suggests a reason: far less than a majority of the American public supports multilateralism in aid. Elites in our sample show the same preferences for bilateral policies, and their partisan debates over multilateralism are reflected in all likelihood in public attitudes. This weak support arises despite evidence that multilateralism is more effective than bilateralism. Moreover, it contrasts with other donor countries, who give a greater percentage of multilateral aid and have stronger public support for multilateralism (Milner 2006). Policy makers in the US choose low levels of multilateral giving, elites in the US are divided over the use of international institutions, and public opinion reflects this.

The data provide support for a principal-agent model. Principals face a trade-off between two goals, burden sharing versus control, which we see reflected in our surveys. On the one hand, delegating power to an agent like the World Bank can result in better decisions and more efficient use of aid. World Bank coordination can reduce collective action problems and prevent countries from free riding. On the other hand, the principals lose some control, and some principals lose more control than others. The World Bank, through a consensual process in which the US plays an important role, decides where aid goes and what projects it supports. To the extent that the preferences of the decision makers in the World Bank are close to those of the US, this loss of control is less 
worrisome. However, the US has important domestic political divisions that extend to foreign policy. In terms of the goals of foreign aid, Democrats tend to hold policy preferences closer to those of the World Bank than do Republicans. This preference divergence means that Republicans worry more about control in aid delegation, and helps explain why they support multilateralism less than Democrats. As the literature in American politics has shown, delegation domestically is a highly partisan issue: "Congress gives less discretionary authority to executive agencies controlled by the opposite party, reducing agencies' latitude.... [and] these changes in executive discretion had an appreciable impact on policy outcomes" (Epstein and O'Halloran 1999, pg. 235). Partisan contestation over multilateralism is thus understandable from a principal-agent perspective.

While we bring new data to bear on this important topic, there are limitations to our study. First, our YouGov surveys cover only a 3 year slice of time (2008-10) and their results could be affected by events surrounding that period. We think that this period should have been one that was favorable to multilateralism since it came after a period of strong unilateral actions by the US which often had costly consequences for the country. A plurality of the public in late 2008 supported the Democratic candidate for president, and he was a strong multilateral supporter. If anything, our results may overstate the case for multilateralism.

Second, we gathered public opinion data, and it is useful to the extent that it bears some relation to the policy process. Other public opinion studies point out that public attitudes often set constraints on political leaders and their policy choices. In addition, the two-way street between publics and elites in democracies implies that elite views and debates tend to be reflected in public opinion. As both of these views would lead one to expect, our sub-sample of individuals who resemble foreign policy elites shares many of the same attitudes as the overall public. Public opinion then should be informative. Our data represents a first new step, and we hope that other types of data will be brought to bear on the choice for multilateralism.

Third, we have investigated only the US. Other donor countries may differ significantly. Some give much larger proportions of multilateral aid. And in Europe the structure of domestic preferences may differ greatly from that in the US. We think future research should attempt to investigate the choice for multilateralism outside the US. One bit of evidence that we do have about other countries is consistent with our argument, however. Evidence from the TRIP survey using non-American IR scholarsmostly Europeans - suggests that more socially conservative scholars oppose multilateral aid more than their liberal colleagues. Although suggestive, we believe that larger, more representative surveys, like ours in the US, would be a helpful addition.

Since multilateralism is often about delegation to an international institution, our research has implications for theories of international institutions. Previous studies have argued that such institutions are demanded by states to the extent that they reduce transaction costs or allow powerful countries to bind themselves credibly (Ikenberry 2003; Lake 1999). Our project presents a more complex view of international institutions. Principal-agent models show that the benefits of delegation can be reduced transaction costs and enhanced collective action (Epstein and O'Halloran 1999). But the loss of control involved raises issues about the distribution of benefits from delegation to international institutions. Realists have focused on relative gains among states (Gruber 2000; Krasner 1978). The distributive problem here is domestic. Some domestic actors may pay higher costs for delegation to international 
institutions than others because their preferences may be less congruent with those of the institution. Multilateralism as a form of delegation may thus raise thorny domestic political issues. While it may reduce international transaction costs and induce greater collective action, delegation to multilateral institutions may create and/or exacerbate domestic distributional struggles.

\section{References}

Aldrich, J. H., Sullivan, J. L., \& Borgida, E. (1989). Foreign affairs and issue voting: Do presidential candidates "waltz before a blind audience?". American Political Science Review, 83, 123-141.

Aldrich, J., Gelpi, C., Feaver, P., Reifler, J., \& Sharp, K. (2006). Foreign policy and the electoral connection. Annual Review of Political Science, 9, 477-502.

Baldwin, D. (1986). Economic statecraft. Princeton: Princeton University Press.

Balogh, T. (1967). Multilateral versus bilateral aid. Oxford Economic Papers, 19, 332-344.

Berinsky, A. (2007). Assuming the costs of war: Events, elites, and American public support for military conflict. Journal of Politics, 69, 975-997.

Boas, M., \& McNeil, D. (2003). Multilateral institutions: A critical introduction. London: Pluto Press.

Broz, L. (2008). Congressional voting on funding the international financial institutions. The Review of International Organizations, 3, 351-374.

Bueno de Mesquita, B., \& Smith, A. (2007). Foreign aid and policy concessions. Journal of Conflict Resolution, 51, 251-284.

Busby, J. W., \& Monten, J. (2008). Without heirs? Assessing the decline of establishment internationalism in U.S. foreign policy. Perspectives on Politics, 6, 451-472.

Campbell, C., Rae, N., \& Stack, J. (2003). Congress and the politics of US foreign policy. Upper Saddle Ridge: Prentice Hall.

Canes-Wrone, B. (2006). Who leads whom? Presidents, policy, and the public. Chicago: University of Chicago Press.

Chicago Council. (2005). Global views 2004: American public opinion and foreign policy. Chicago Council on Foreign Relations.

Chittick, W., Billingsley, K., \& Travis, R. (1995). A three-dimensional model of American foreign policy beliefs. International Studies Quarterly, 39, 313-331.

Clist, P. (2011). 25 years of aid allocation practice: Whither selectivity? World Development, 39, 1724-1734.

Congressional Record. (1977). Congressional record. June 23.

Congressional Record. (1993). Congressional record. June 17.

Cowhey, P. F. (1993). Elect locally-Order globally: Domestic politics and multilateral cooperation. In Multilateralism matters. In J. G. Ruggie (Ed.), The theory and practice of an institutional form, (pp. 157-200). New York: Columbia University Press.

Deudney, D. (2007). Bounding power: Republican security theory from the polis to the global village. Princeton: Princeton University Press.

Dreher, A., \& Jensen, N. M. (2007). Independent actor or agent? An empirical analysis of the impact of US interests on IMF conditions. Journal of Law and Economics, 50, 105-124.

Easterly, W., \& Pfutze, T. (2008). Best practice for foreign aid: Who knows where the money goes? Journal of Economic Perspectives, Spring.

Epstein, D., \& O'Halloran, S. (1999). Delegating powers: A transaction cost politics approach to policy making under separate powers. Cambridge: Cambridge University Press.

Erikson, R. S., MacKuen, M. B., \& Stimson, J. A. (2002). The macro polity. New York: Cambridge University Press.

Finnemore, M. (1996a). Constructing norms of humanitarian intervention. In K. Katzenstein (Ed.), The culture of national security: Norms and identity in world politics ( $\mathrm{pp}$ 153-185).

Finnemore, M. (1996b). National interest in international society. Ithaca: Cornell University Press.

Fleck, R., \& Kilby, C. (2006a). World Bank independence: A model and statistical analysis of US influence. Review of Development Economics, 10, 224-240.

Fleck, R. K., \& Kilby, C. (2006b). How do political changes influence US bilateral aid allocations? Evidence from panel data. Review of Development Economics, 10, 210-223.

Gruber, L. (2000). Ruling the world: Power politics and the rise of supranational institutions. Princeton: Princeton University Press. 
Gutner, T. (2005). Explaining the gaps between mandate and performance: Agency theory and World Bank environmental reform. Global Environmental Politics, 5, 10-36.

Gutner, T., \& Thompson, A. (2010). The politics of international organization performance: A framework. Review of International Organization, 5, 227-248.

Gwin, C. (1994). U.S. relations with the World Bank, 1945-1992. Washington: Brookings Institution.

Hagen, R. J. (2006). Samaritan agents? On the strategic delegation of aid policy. Journal of Development Economics, 79, 249-263.

Hawkins, D. G., Lake, D. A., Nielson, D. L., \& Tierney, M. (2006). Delegation and agency in international organizations. Cambridge: Cambridge University Press.

Holsti, O. R. (2004). Public opinion and American foreign policy. Ann Arbor: University of Michigan Press.

Holsti, O., \& Rosenau, J. (1984). American leadership in world affairs: Vietnam and the breakdown of consensus. Boston: Allen and Unwin.

Holsti, O., \& Rosenau, J. (1986). Consensus lost. Consensus regained?: Foreign policy beliefs of American leaders, 1976-1980. International Studies Quarterly, 30, 375-409.

Hooghe, L. (2003). Europe divided?: Elites vs. public opinion on European integration. European Union Politics, 4, 281-304.

House. (1972). House committee on appropriations, foreign assistance and related programs appropriation bill, 1972, report 92-711.

House. (1977). House committee on appropriations, foreign assistance and related programs appropriation bill, 1978 , report $95-417$.

Huber, J. D., \& Shipan, C. R. (2002). Deliberate discretion: The institutional foundations of bureaucratic autonomy. New York: Cambridge University Press.

Ikenberry, G. J. (2001). After victory: Institutions, strategic restraint, and the rebuilding of order after major wars. Princeton: Princeton University Press.

Ikenberry, G. J. (2003). Is American multilateralism in decline? Perspectives on Politics, 1, 533-550.

Jepperson, R. L., Wendt, A., \& Katzenstein, P. (1996). Norms, identity, and culture in national security. In P. J. Katzenstein (Ed.), The culture of national security: Norms and identity in world politics. New York: Columbia University Press.

Kirk, M. (2007). End World Bank disbursements to Iran. http://www.juf.org/news/local.aspx?id=26648.

Knack, S., \& Rahman, A. (2008). Donor fragmentation. In W. Easterly (Ed.), Reinventing foreign aid. Cambridge: Cambridge University Press.

Krasner, S. (1978). Defending the national interest: Raw materials investments and US foreign policy. Princeton: Princeton University Press.

Kupchan, C., \& Trubowitz, P. (2007). Dead center: The demise of liberal internationalism in the United States. International Security, 32, 7-44.

Kuziemko, I., \& Werker, E. (2006). How much is a seat on the security council worth? Foreign aid and bribery at the United Nations. Journal of Political Economy, 114, 905-930.

Lake, D. A. (1999). Entangling relations: American foreign policy in its century. Princeton: Princeton University Press.

Lake, D. A. (2009). Hierarchy in international relations. Ithaca: Cornell University Press.

Lumsdaine, D. H. (1993). Moral vision in international politics: The foreign aid regime 1949-1989. Princeton: Princeton University Press.

Lupia, A. (1994). Shortcuts versus encyclopedias: Information and voting behavior in California insurance reform elections. American Political Science Review, 88, 63-76.

Maizels, A., \& Nissanke, M. K. (1984). Motivations for aid to developing countries. World Development, 12, 879-900.

Maliniak, D., Peterson, S., Tierney, M. (2012). TRIP around the world: Teaching, research, and policy views of international relations faculty in 20 countries, teaching, research, and international policy (TRIP) project (William and Mary).

Mansfield, E., \& Mutz, D. (2009). Support for free trade: Self-interest, sociotropic politics, and out-group anxiety. International Organization, 63, 425-457.

Martens, B., Mummert, U., Murrell, P., \& Seabright, P. (2002). The institutional economics of foreign aid. Cambridge: Cambridge University Press.

Martin, L. (2006). Distribution, information, and delegation to international organizations: The case of IMF conditionality. In D. Hawkins, D. A. Lake, D. Nielson, M. J. Tierney (Eds.), Delegation and agency in international organizations (pp 140-164).

Mason, E. S., \& Asher, R. E. (1973). The World Bank since Bretton Woods. Washington: The Brookings Institution. 
McCarty, N., Poole, K., \& Rosenthal, H. (2006). Polarized America: The dance of ideology and unequal riches. Cambridge: MIT Press.

McKeown, T. J. (2009). How U.S. decision-makers assessed their control of multilateral organizations, 1957-1982. Review of International Organization, 4, 269-291.

Milner, H. (2006). Why multilateralism? Foreign aid and domestic principal-agent problems. In D. G. Hawkins et al. (Eds.), Delegation and agency in international organizations (pp. 107-139). New York: Cambridge University Press.

Milner, H., \& Tingley, D. (2010). The domestic politics of foreign aid: American legislators and the politics of donor countries. Economics and Politics, 22, 200-232.

Milner, H., \& Tingley, D. (2011). Who supports global economic engagement? The sources of preferences in American foreign economic policy. International Organization, 65, 37-68.

Mondak, J. (2001). Developing valid knowledge scales. American Journal of Political Science, 45, $224-238$.

Nielson, D., \& Tierney, M. (2003). Delegation to international organizations: Agency theory and World Bank environmental reform. International Organization, 57, 241-276.

OECD/DAC. (2006). The United States: DAC peer review. http://www.oecd.org/dataoecd/61/57/ 37885999.pdf.

Olson, M. J., \& Zeckhauser, R. (1966). An economic theory of alliances. The Review of Economics and Statistics, 48, 266-279.

Page, B., \& Shapiro, R. Y. (1992). The rational public: 50 years of trends in Americans' policy preferences. Chicago: University of Chicago Press.

PIPA. (2001). Americans on foreign aid and world hunger: A study of US public attitudes. http:// www.worldpublicopinion.org/pipa/pdf/feb01/ForeignAid_Feb01_rpt.pdf.

Pollack, M. A. (2003). The engines of European integration: Delegation, agency and agenda setting in the $E U$. New York: Oxford University Press.

Rajan, R. G., \& Subramanian, A. (2008). Aid and growth: What does the cross-country evidence really show? The Review of Economics and Statistics, 90, 643-665.

Risse-Kappen, T. (1996). Collective identity in a democratic community: The case of NATO. In: P. Katzenstein (Ed.), The culture of national security (pp 357-399).

Rodrik, D. (1996). Why is there multilateral lending? In M. Bruno \& B. Pleskovic (Eds.), Annual World Bank conference on development economics, 1995 (pp. 167-193). Washington: IMF.

Rubin, R. E. (1999). Subcommittee on foreign operations, export financing, and related programs. Senate Appropritions Subcommittee Hearings, 3/17/1999.

Ruggie, J. G. (1993). Multilateralism matters: The theory and praxis of an institutional form. New York: Columbia University Press.

Sniderman, P. M., Brody, R. A., \& Tetlock, P. E. (1991). Reasoning and choice: Explorations in political psychology. New York: Cambridge University Press.

Stone, R. (2002). Lending credibility: The international monetary fund and the post-communist transition. Princeton: Princeton University Press.

Stone, R. (2011). Controlling institutions: International organizations and the global economy. Cambridge: Cambridge University Press.

Svensson, J. (2000). When is foreign aid policy credible? Aid dependence and conditionality. Journal of Development Economics, 61, 61-84.

Tallberg, J. (2002). Paths to compliance: Enforcement, management, and the European Union. International Organization, 56, 609-643.

Tierney, M. (2006). Delegation under anarchy: States, international organizations and principal agent theory. In: D. G. Hawkins, D. A. Lake, D. L. Nielson, M. Tierney (Eds.), Delegation and agency in international organizations. Cambridge University Press.

Tingley, D. (2010). Donors and domestic politics: Political influences on foreign aid commitments. The Quarterly Review of Economics and Finance, 50, 40-49.

Trubowitz, P. (1992). Sectionalism and American foreign policy: The political geography of consensus and conflict. International Studies Quarterly, 36, 173-190.

Voeten, E. (2001). Outside options and the logic of security council action. American Political Science Review, 95, 845-858.

Weiss, M. A., \& Sanford, J. E. (2008). The World Bank and Iran. Congressional Research Service http:// www.fas.org/sgp/crs/mideast/RS22704.pdf.

Wroughton, L. (2008). U.S. lawmakers and World Bank seek to bridge gaps. Reuters http:// www.reuters.com/article/idUSN16483392.

Zaller, J. (1992). The nature and origins of mass opinion. Cambridge: Cambridge University Press. 